\title{
Potencjal małych i średnich przedsiębiorstw regionu południowego
}

Przedsiębiorczość w Polsce jest zróżnicowana regionalnie. Ogromna większość małych i średnich przedsiębiorstw działa w pięciu województwach (mazowieckim, śląskim, wielkopolskim, dolnośląskim, małopolskim). W ujęciu regionów statystycznych stworzonych na potrzeby europejskiej nomenklatury statystycznej, region południowej Polski jest jednym z liderów pod względem wskaźnika przedsiębiorczości. Dotychczas brak jest zarówno analiz przekrojowych w tej mierze, jak i porównawczych w ujęciu regionalnym (czyli według klasyfikacji NUTS-1, a nie w ujęciu województw zgodnie z klasyfikacją NUTS-2). Spowodowane jest to sztucznym podziałem Polski na sześć dużych regionów statystycznych. Interesujące jednak wydaje się sporządzenie takiej analizy, celem artykułu jest zatem diagnoza sytuacji społeczno-ekonomicznej regionu południowego (region II według klasyfikacji NUTS-1) z uwzględnieniem stanu i tendencji rozwoju małych i średnich przedsiębiorstw w ujęciu dynamicznym.

\section{Struktura społeczno-ekonomiczna regionu południowego ${ }^{1}$}

Region południowy został wyróżniony dla potrzeb nomenklatury statystycznej 1.05.2004 r. (z dniem wejścia Polski do Unii Europejskiej) na mocy rozporządzenia Rady Ministrów RP (Rozporządzenie..., 2004). Obejmuje on dwa województwa: małopolskie i śląskie; siedem podregionów (trzy w woj. małopolskim: krakowsko-tarnowski, miasto Kraków, nowosądecki oraz cztery w woj. śląskim: częstochowski, centralny śląski, rybnicko-jastrzębski i bielsko-bialski); 36 powiatów (19 w woj. małopolskim i 17 w woj. śląskim) oraz 349 gmin (182 w woj. małopolskim i 167 w woj. śląskim).

W regionie powstały ośrodki szczególnej koncentracji przedsiębiorczości prywatnej (małych i średnich przedsiębiorstw prywatnych), przy jednoczesnym zacofaniu ośrodków peryferyjnych (Dębski 2002a, 2002b). Na podstawie wyników badań J. Dębskiego, w regionie południowym można wyróżnić lokalne i regionalne ośrodki wzrostu przedsiębiorczości prywatnej (Dębski 2002a). W tym regionie autor wyróżnia 5 regionalnych ognisk wzrostu przedsiębiorczości prywatnej ( 2 w woj. małopolskim: Kraków, Tarnów oraz 3 w woj. śląskim: Częstochowa, Bielsko-Biała oraz konurbacja górnośląska: Katowice, Gliwice, Sosnowiec, Zabrze, Bytom, Tychy, Rybnik, Dąbrowa Górnicza, Chorzów) oraz 5 lokalnych biegunów wzrostu przedsiębiorczości prywatnej (1 w woj. małopolskim: Spytkowice oraz 4 w woj. śląskim: Jejkowice, Starcza, Ślemień, Krupski Młyn). W 2003 r. Centrum Badań Regionalnych w Warszawie sporządziło ranking potencjału rozwojowego miast polskich, którym objęto 839 miast, zgodnie z kryteriami OECD w zakresie gęstości

\footnotetext{
${ }^{1}$ Profil społeczno-ekonomiczny regionu południowego sporządzono głównie na podstawie danych statystycznych GUS (zarówno publikowanych, jak i udostępnionych na zamówienie). Wykorzystano także publikacje Centrum Badań Regionalnych w Warszawie, Instytutu Badań nad Gospodarką Rynkową w Gdańsku, Urzędu Marszałkowskiego Województwa Małopolskiego oraz Urzędu Marszałkowskiego Województwa Śląskiego. Przytaczane dane, jeśli nie wskazano inaczej, odnoszą się do 2004 r.
} 
zaludnienia (Wielki Ranking... 2003). W regionie południowym znajduje się aż 29 miast o największym w Polsce potencjale rozwojowym, z których 9 zaklasyfikowano jako ,ekstraklasa” (6 w woj. małopolskim, pozostałe $3 \mathrm{w}$ woj. śląskim), 20 miast jako ,pierwsza klasa” (13 w woj. małopolskim, 8 w woj. śląskim) ${ }^{2}$. Dominującą pozycję w woj. małopolskim odgrywa Kraków, który jest nie tylko regionalnym, ale i krajowym ogniskiem wzrostu, które oddziałuje na sąsiednie województwa, zwłaszcza w zakresie szkolnictwa wyższego oraz działalności naukowo-badawczej i kulturalnej (Dębski 2002a). W woj. śląskim decydujące znaczenie odgrywa konurbacja górnośląska (z Katowicami na czele), a także Częstochowa oraz Bielsko-Biała. O ile regionalne ogniska wzrostu są jednoznacznie określone, o tyle lokalne bieguny wzrostu nie są zbyt silnie wyodrębnione. Rozwój gmin peryferyjnych pozostaje w tyle (niekiedy daleko) za ośrodkami o znaczeniu regionalnym (konurbacja górnośląska w woj. śląskim oraz Kraków w woj. małopolskim).

W ujęciu sześciu regionów najwyższą ocenę atrakcyjności inwestycyjnej w Polsce w $2005 \mathrm{r}$. uzyskał region południowy (region centralny znalazł się na 2 pozycji) w świetle badań nad przestrzennym zróżnicowaniem atrakcyjności inwestycyjnej Polski prowadzonych od $1994 \mathrm{r}$. przez Instytut Badań nad Gospodarką Rynkową w Gdańsku (Atrakcyjność... 2005). Do najwyższej klasy atrakcyjności inwestycyjnej w przekroju województw zaszeregowane zostały (oprócz woj. mazowieckiego - klasa A, ranga 2) zarówno woj. śląskie (klasa A, ranga 1), jak i małopolskie (klasa A, ranga 3). Najwyższe oceny uzyskały takie cechy cząstkowe (por. tab. 1), jak zasoby i koszty pracy, dostępność transportowa, poziom rozwoju infrastruktury gospodarczej, poziom rozwoju infrastruktury społecznej (woj. śląskie uzyskało dodatkowo najwyższą ocenę w kryterium chłonności wojewódzkiego rynku zbytu). Bardzo interesujące są również klasyfikacje przestrzenne regionu. Trzy podregiony regionu południowego charakteryzują się najwyższą w Polsce

Tab. 1. Ocena atrakcyjności inwestycyjnej regionu południowego w 2005 r.

\begin{tabular}{|l|c|c|c|}
\hline \multicolumn{1}{|c|}{ Kryterium cząstkowe $^{\mathbf{1}}$} & $\begin{array}{c}\text { Region } \\
\text { poludniowy }\end{array}$ & Woj. małopolskie & Woj. śląskie \\
\hline Dostępność transportowa & $\mathrm{A}$ & $\mathrm{A}$ & $\mathrm{A}$ \\
\hline Zasoby i koszty pracy & $\mathrm{A}$ & $\mathrm{A}$ & $\mathrm{A}$ \\
\hline Chłonność rynku zbytu & $\mathrm{A}$ & $\mathrm{B}$ & $\mathrm{A}$ \\
\hline Infrastruktura gospodarcza & $\mathrm{A}$ & $\mathrm{A}$ & $\mathrm{A}$ \\
\hline Infrastruktura społeczna & $\mathrm{A}$ & $\mathrm{A}$ & $\mathrm{A}$ \\
\hline Poziom bezpieczeństwa powszechnego & $\mathrm{D}$ & $\mathrm{D}$ & $\mathrm{E}$ \\
\hline Aktywność wobec inwestorów & $\mathrm{B}$ & $\mathrm{B}$ & $\mathrm{C}$ \\
\hline Ogólna atrakcyjność inwestycyjna $^{3}$ & $\mathrm{~A}$ & $\mathrm{~A}$ & A \\
\hline
\end{tabular}

${ }^{1}$ Do ewaluacji zastosowano pięć klas (A-E, spośród których A jest najlepsza) oraz szesnaście rang.

${ }^{2}$ Oceny dla regionu stanowią średnią rang i klas dla woj. małopolskiego i woj. śląskiego.

${ }^{3}$ Ocena ogólna jest wypadkową wartości wskaźników cząstkowych.

Źródło: opracowanie autora na podstawie: Atrakcyjność inwestycyjna województw i podregionów Polski 2005, 2005, T. Kalinowski (red.), Instytut Badań nad Gospodarką Rynkową, Gdańsk

\footnotetext{
${ }^{2}$ Syntetyczny wskaźnik potencjału rozwojowego miast został skonstruowany przez Centrum Badań Regionalnych w Warszawie na podstawie czterech czynników cząstkowych: aktywność gospodarcza, aktywność obywatelska, infrastruktura miejska, przyciaganie nowych mieszkańców.
} 
atrakcyjnością inwestycyjną dla działalności przemysłowej. Są to centralny śląski (pozycja 1), rybnicko-jastrzębski (pozycja 2), krakowsko-tarnowski łącznie z miastem Kraków (pozycja 3). Podregion bielsko-bialski znalazł się na piątym miejscu. W pierwszej piątce rankingu atrakcyjności inwestycyjnej dla działalności usługowej znalazły się aż trzy podregiony wchodzące w skład regionu południowego: centralny śląski (pozycja 2), krakowsko-tarnowski łącznie z miastem Kraków (pozycja 4) oraz bielsko-bialski (pozycja 5), a podregion częstochowski znalazł się na ósmym miejscu. Również trzy podregiony zostały uznane za jedne z najbardziej atrakcyjnych inwestycyjnie dla działalności zaawansowanej technologicznie: centralny śląski (pozycja 3), krakowsko-tarnowski łącznie z miastem Kraków (pozycja 4) oraz bielsko-bialski (pozycja 6).

Zgodnie z planami rozwoju województw małopolskiego i śląskiego, w regionie południowym można wyodrębnić kilka obszarów strategicznego rozwoju. Na podstawie szczegółowej diagnozy w woj. małopolskim wyróżniono trzy obszary rozwojowe: obszar rozwoju rolnictwa (północny); obszar intensywnego rozwoju gospodarczego (środkowy, wokół istniejącej i planowanej autostrady A4); obszar rozwoju turystyki (południowy). Analogicznie w woj. śląskim wyodrębniono cztery obszary polityki rozwoju województwa: obszar rozwoju rolnictwa (północny, wokół aglomeracji częstochowskiej); obszar rozwoju turystyki (południowy, wokół aglomeracji bielskiej) oraz dwa obszary intensywnego rozwoju gospodarczego (środkowy oraz zachodni), przy czym obszar środkowy (wokół aglomeracji górnośląskiej) cechuje się zróżnicowaniem funkcji rozwoju cywilizacyjnego i gospodarczego, zrestrukturyzowaną gospodarką z dużą liczbą przedsiębiorstw zaawansowanych technologii oraz koncentracją sfery usług, a obszar zachodni (wokół aglomeracji rybnickiej) ma zróżnicowaną strukturę gospodarczą z ograniczonym wydobyciem węgla kamiennego, dobrze rozwiniętą sieć małych i średnich przedsiębiorstw o profilu usługowym i wytwórczym (Strategie rozwoju... 2005). Można zaobserwować podobieństwa w przestrzennym rozmieszczeniu obszarów rozwojowych obydwu województw, na co wskazuje logiczne ich rozmieszczenie w całym regionie południowym (ryc. 1).

Ryc. 1. Obszary rozwojowe regionu południowego

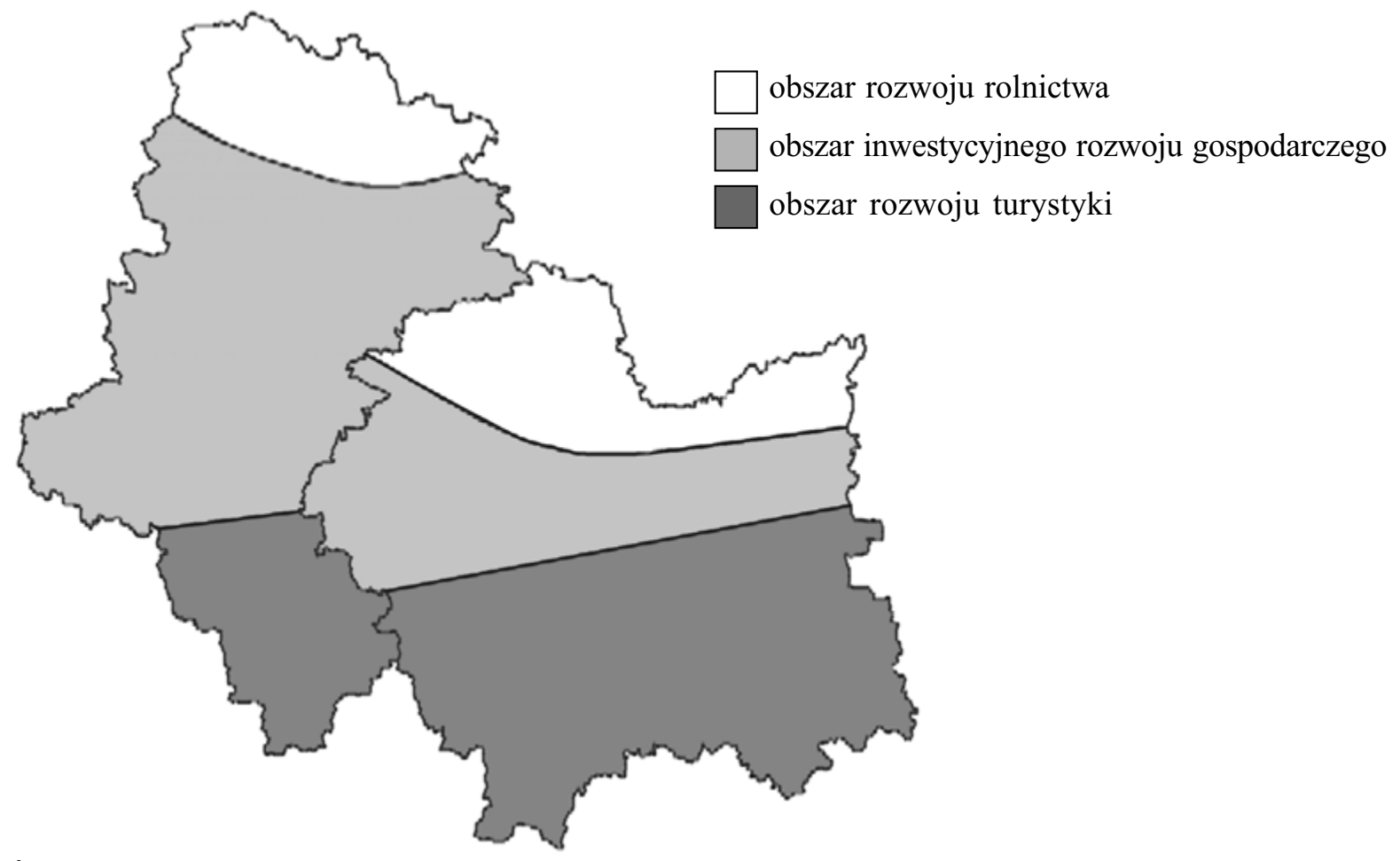

Źródło: opracowanie autora 
Potencjał rozwojowy jest bardzo zróżnicowany zarówno w regionie, jak w województwach. Najwyższy potencjał występuje w Krakowie, Katowicach, Dąbrowie Górniczej, Rudzie Śląskiej, Tarnowie, Nowym Sączu, a także powiatach bielskim i tatrzańskim (Surażka 1999). Woj. małopolskie jest zdominowane przez potencjał Krakowa, poza którym (oprócz Tarnowa i Podhala) potencjał rozwojowy jest bardzo niski. Głównym źródłem potencjału rozwojowego województwa jest (nie do końca wykorzystane) potężne zaplecze naukowo-badawcze ${ }^{3}$. Drugą determinantą rozwoju jest atrakcyjność turystyczna regionu, jednak słabe wyposażenie w odpowiednią infrastrukturę turystyczną uniemożliwia pełne wykorzystanie tego czynnika. Cechą charakterystyczną woj. śląskiego w stosunku do innych województw jest duża chłonność rynku, wyznaczona głównie gęstością zaludnienia i dochodami ludności.

Region południowy jest drugim (po regionie centralnym) najsilniejszym gospodarczo regionem Polski, przy czym w układzie województw woj. śląskie zajmuje pozycję 2, a małopolskie - 5 . W regionie w 2003 r. wytworzono 21,1\% PKB Polski (w tym woj. śląskie 13,7\%, a woj. małopolskie 7,4\%). Region południowy wytworzył w 2003 r. łącznie $21,1 \%$ wartości dodanej brutto Polski, co niewątpliwie stanowi o sile gospodarczej regionu. Warto jednak zaznaczyć, że znaczący udział ma woj. śląskie, wytwarza ono bowiem niemal dwa razy więcej wartości dodanej brutto w skali kraju niż woj. małopolskie.

Rozmieszczenie ośrodków wspierania innowacji przedsiębiorstw jest bardzo zróżnicowane w regionie. W woj. małopolskim ośrodki koncentrują się w obrębie miasta Kraków ${ }^{4}$, a w woj. śląskim można zaobserwować silną tendencję do ich skupienia w konurbacji górnośląskiej (Katowice, Sosnowiec, Tychy, Gliwice, Będzin $)^{5}$. Pomiędzy lokalizacją instytucji proinnowacyjnych a koncentracją przemysłów zaawansowanych technologii w poszczególnych powiatach występuje silna korelacja wynosząca 0,72 (Ośrodki innowacji... 2005). Jeden ośrodek proinnowacyjny zlokalizowany w regionie południowym pociagga za sobą koncentrację 3,9 branż wysoko i średnio zaawansowanych technologicznie, co jest najwyższym wskaźnikiem w skali kraju. W rozkładzie przestrzennym współczynnik ten dla woj. małopolskiego wynosi 2, a dla śląskiego 4,8 (ryc. 2) ${ }^{6}$.

W celu podniesienia konkurencyjności polskich małych i średnich przedsiębiorstw poprzez dostarczenie im wysokiej jakości kompleksowych usług, w 1996 r. powołano sieć ośrodków w ramach Krajowego Systemu Usług (KSU) dla małych i średnich przedsiębiorstw. Ośrodki są nadzorowane i certyfikowane przez Polską Agencję Rozwoju Przedsiębiorczości, a specjalizują się w świadczeniu usług doradczych, informacyjnych, szkoleniowych, finansowych i proinnowacyjnych. Pod względem liczby ośrodków KSU region południowy znajduje się na drugiej pozycji w kraju (39 ośrodków, lepsze miejsce zajmuje region wschodni-41 ośrodków), przy czym w ujęciu województw śląskie jest ogólnopolskim liderem (28 ośrodków), a małopolskie (11 ośrodków) sytuuje się poniżej średniej dla Polski i zajmuje miejsce 8.

\footnotetext{
${ }^{3}$ Krakowskie uczelnie i powstałe na ich bazie szkoły wyższe w innych miastach regionu mogą zasilić znacznie bardziej rozbudowany sektor badawczo-rozwojowy niż obecnie istniejący, przyczyniając się rozwoju branż opartych na nowoczesnych technologiach.

${ }^{4}$ W Tarnowie zlokalizowany jest Tarnowski Klaster Przemysłowy „Plastikowa Dolina”, jednak wchodzi on w skład Krakowskiego Parku Technologicznego i nie jest typowym ośrodkiem proinnowacyjnym.

${ }^{5}$ Pozostałe ośrodki zlokalizowane są w Częstochowie i Bielsku-Białej.

${ }^{6}$ Obliczenia autora na podstawie wyników badań przeprowadzonych w 2005 r. przez Instytut Badań nad Gospodarką Rynkową w Gdańsku na zlecenie Polskiej Agencji Rozwoju Przedsiębiorczości.
} 
Ryc. 2. Lokalizacja ośrodków innowacji i przedsiębiorczości w regionie południowym w 2004 r.

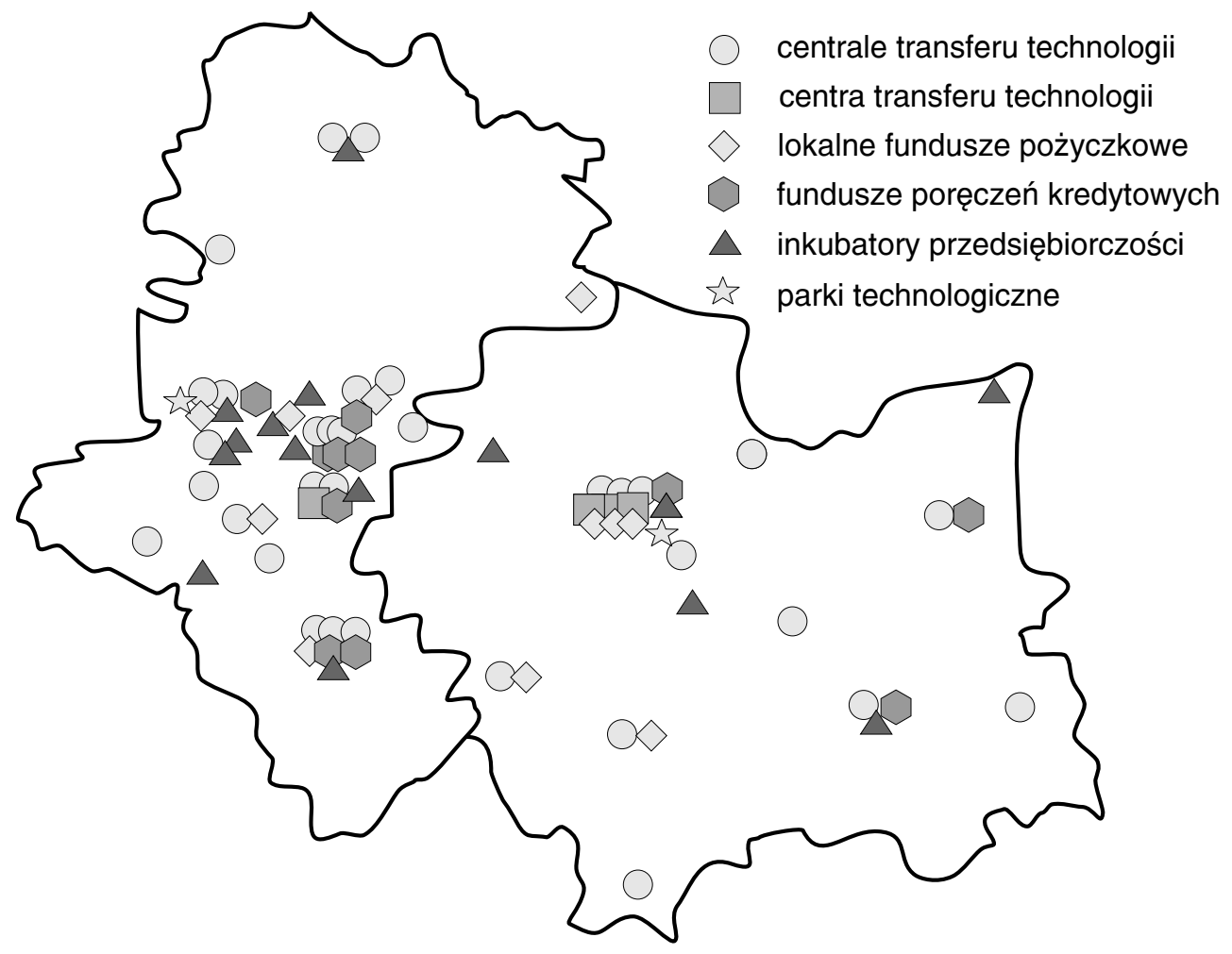

Źródło: Ośrodki innowacji i przedsiębiorczości w Polsce. Raport 2004, 2005, K.B. Matusiak (red.), Instytut Ekonomii Uniwersytetu Łódzkiego, Stowarzyszenie Organizatorów Ośrodków Innowacji i Przedsiębiorczości w Polsce, Poznań-Warszawa

Na podstawie zaprezentowanej analizy sytuacji społeczno-ekonomicznej regionu można sporządzić typogram gospodarczy regionu ${ }^{7}$. Do sporządzenia typogramu potencjału gospodarczego regionu południowego wykorzystano następujące wskaźniki:

- współczynnik urbanizacji, czyli procentowy udział mieszkańców miast w ogólnej liczbie ludności;

- współczynnik aktywności zawodowej, czyli relacja między liczbą ludności w wieku produkcyjnym a zasobami siły roboczej;

- współczynnik przedsiębiorczości osób fizycznych mierzony liczbą przedsiębiorstw osób fizycznych na 1000 mieszkańców;

\footnotetext{
${ }^{8}$ Współczynnik obliczany jest według wzoru: gdzie: $W_{A Z}=\frac{S}{L} * 100 \%$, przy czym $S=Z+B$

W - współczynnik aktywności zawodowej

$\mathrm{S}$ - zasoby sily roboczej

$\mathrm{Z}$ - liczba zatrudnionych

B - liczba bezrobotnych

L - liczba ludności w wieku produkcyjnym
}

${ }^{7} \mathrm{~W}$ pracy zaprezentowano jedynie syntetyczny profil społeczno-ekonomiczny regionu. Szczegółowe informacje zawarte są w opracowaniach w przekroju województw, m.in.: Opis sytuacji spoleczno-ekonomicznej województwa ślaskiego, 2005a oraz Województwo małopolskie 2004, 2005. Obszerne i wnikliwe profile społeczno-ekonomiczne poszczególnych województw i regionów zostały omówione w pracach: Aktualizacja raportu o stanie zagospodarowania przestrzennego kraju, 2003 oraz Regionalne zróżnicowanie rozwoju gospodarczego [w:] Polska 2005. Raport o stanie gospodarki, 2005b). 
- współczynnik wykształcenia wyższego, czyli procentowy udział ludności z wykształceniem wyższym w liczbie ludności ogółem;

- atrakcyjność inwestycyjna ${ }^{9}$;

- stopa bezrobocia;

- PKB na mieszkańca.

Ryc. 3. Typogram regionu południowego na tle Polski

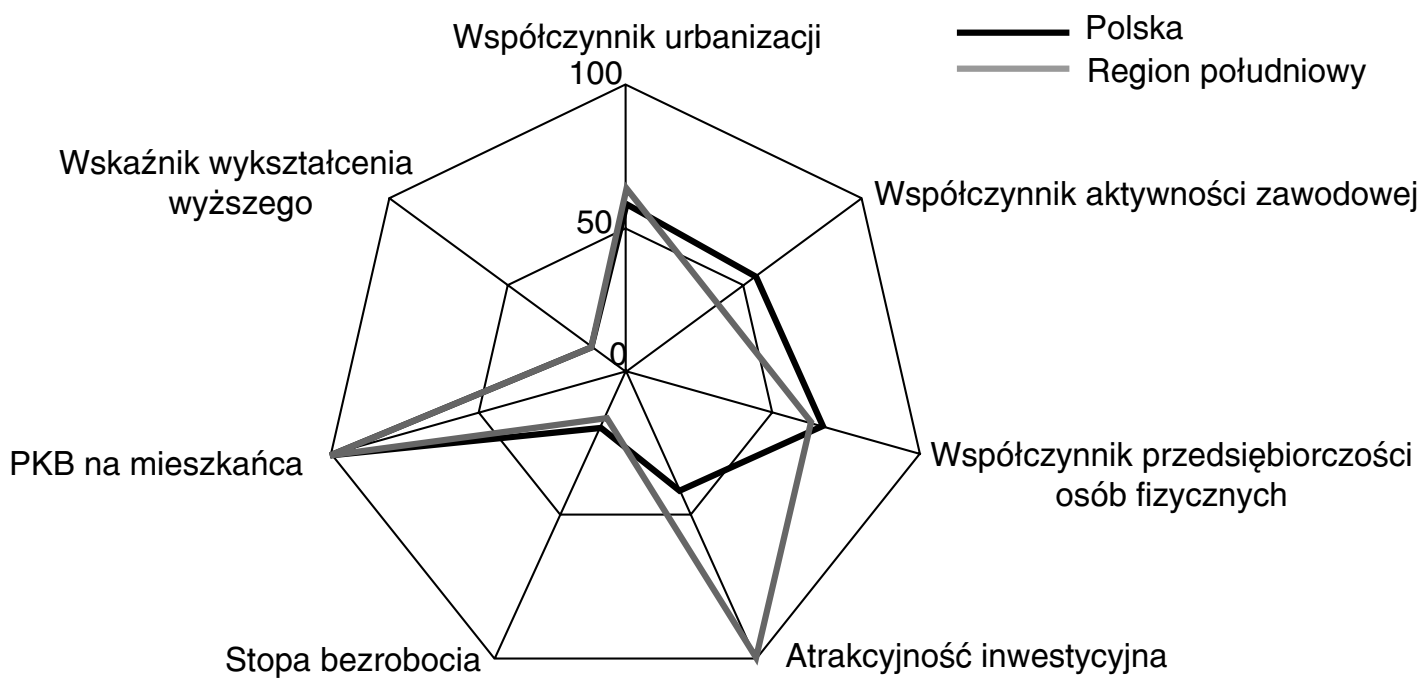

Źródło: opracowanie autora na podstawie danych GUS z 2004 r.

Z analizy wynika, że region południowy charakteryzuje się wyższymi wskaźnikami potencjału gospodarczego niż uśrednione wskaźniki w skali kraju (ryc. 3), w ujęciu województw woj. śląskie ma wyższy potencjał niż woj. małopolskie (ryc. 4). Warto zwrócić uwagę, że wcześniej przytoczone rankingi atrakcyjności inwestycyjnej potwierdzają trafność takiego doboru wskaźników (wnioski z obydwu analiz są zbliżone). Woj. malopolskie ma ogromny niewykorzystany potencjał naukowo-badawczy oraz turystyczny, co pozwala na optymistyczne prognozy rozwoju województwa, a nawet regionu, który pozostaje pod wpływem Krakowa - aglomeracji o zasięgu ponadregionalnym.

Ryc. 4. Typogram porównawczy województw regionu południowego

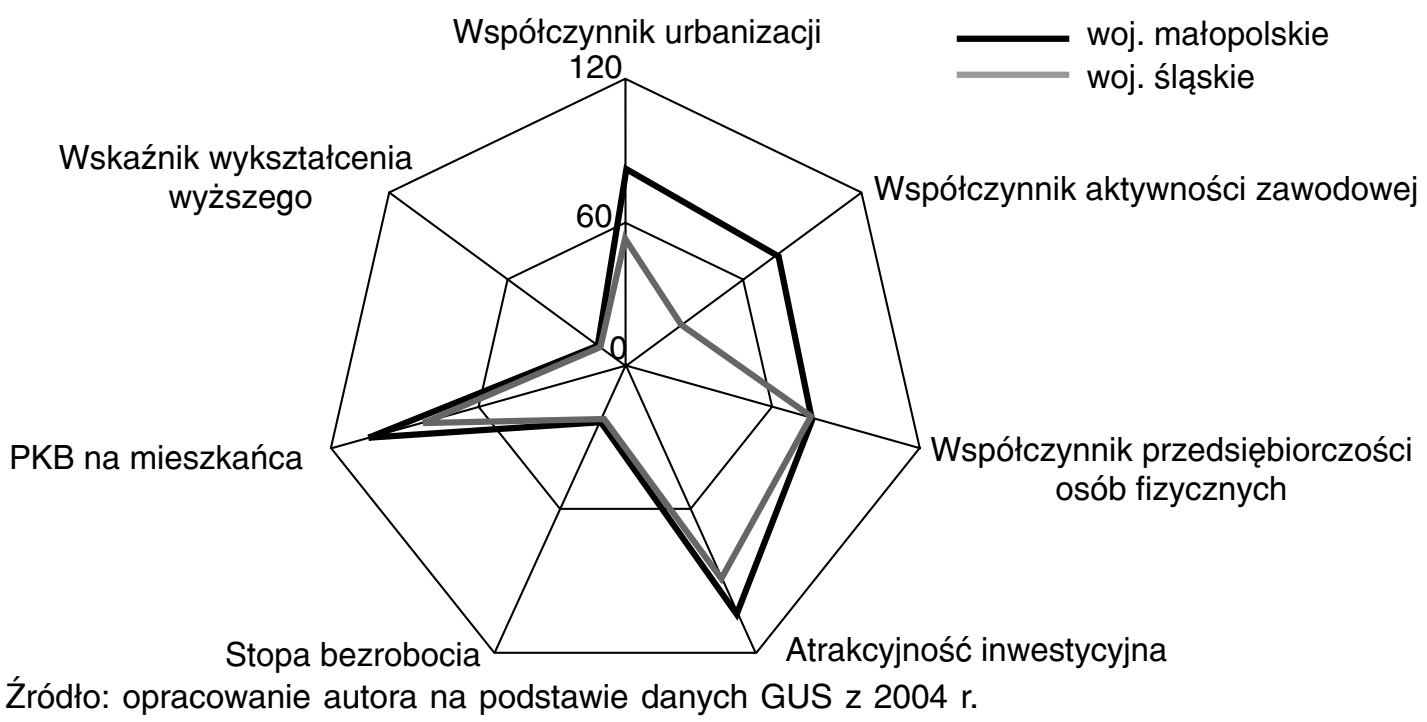

\footnotetext{
${ }^{9}$ Wykorzystano miarę zaproponowaną przez Instytut Badań nad Gospodarką Rynkową w Gdańsku (patrz wyżej).
} 


\section{Małe i średnie przedsiębiorstwa w województwach małopolskim i śląskim}

Początek lat 90. XX w. przyniósł w Polsce rozwój przedsiębiorczości prywatnej, również w układzie regionalnym. Powszechny i równy dostęp obywateli do wielu gałęzi gospodarki stworzył ogromne szanse rozwoju prywatnej przedsiębiorczości. Zniesienie wielu barier prawnych, charakterystycznych dla gospodarki etatystycznej, ograniczających rozwój przedsiębiorczości, pozwoliło obywatelom na tworzenie własnych firm. Nowe warunki funkcjonowania gospodarki okazały się ogromną szansą dla rozwoju przedsiębiorczości, zwłaszcza dla małych i średnich firm prywatnych. Dodatkowym czynnikiem mającym istotny wpływ na rozwój przedsiębiorczości było duże zapotrzebowanie rynku na wszelkiego rodzaju dobra i usługi. Szczególnie szanse te wykorzystały przedsiębiorstwa z sektora MSP, co zaowocowało imponującym przyrostem ich liczby. Społeczeństwo żyjące we wciąż zmieniających się warunkach wykształca przedsiębiorczy klimat, ćwiczy kreatywność i skłonność do podejmowania inicjatyw. Dane statystyczne jednoznacznie wskazuja, że podmioty sektora prywatnego w Polsce na przełomie XX i XXI w. charakteryzowały się ogromną dynamiką wzrostu, co przyspieszyło procesy transformacyjne w polskiej gospodarce - przejście od gospodarki socjalistycznej do gospodarki wolnorynkowej. Obecnie przedsiębiorstwa sektora prywatnego stanowią 96,5\% wszystkich przedsiębiorstw w Polsce.

Porównawcze badania międzynarodowe sytuują Polskę wśród państw o średnim poziomie przedsiębiorczości (Przedsiębiorczość w Polsce 2003). Miarą przedsiębiorczości jest w tej mierze procentowy udział osób prowadzących własną działalność gospodarczą lub zarządzających firmą w ogólnej liczbie osób w wieku produkcyjnym, przy uwzględnieniu podmiotów stosunkowo młodych, czyli działających nie dłużej niż 3,5 roku. Niestety, tym, co odróżnia przedsiębiorców w Polsce od przedsiębiorców z innych krajów uczestniczących w badaniu, jest wyjątkowo wysoki odsetek odpowiedzi wiążących rozpoczęcie działalności gospodarczej tylko z koniecznością stworzenia sobie warunków do zarobkowania.

Sektor MSP jest jednym z czynników wzrostu gospodarczego każdego kraju, również Polski. Pozycja tego sektora w Polsce jest co roku wyższa. Jakkolwiek dynamiczny wzrost MSP jest charakterystyczny dla okresu transformacji ekonomicznej w Polsce, pozostaje jednak nadal istotnym czynnikiem wzrostu gospodarczego (tab. 2). W końcu 2005 r. Krajowy Rejestr Urzędowy Podmiotów Gospodarki Narodowej REGON liczył ponad 3,6 mln małych i średnich przedsiębiorstw, co stanowiło 99,9\% wszystkich zarejestrowanych przedsiębiorstw. Największą grupą przedsiębiorstw są firmy najmniejsze, zatrudniające do 9 osób. Stanowią one $95 \%$ ogółu polskich przedsiębiorstw. Udział firm małych (10-49 pracowników) wynosi 4\%, a średnich (50-249 pracowników) - 0,8\%, podczas gdy firmy duże (powyżej 250 pracowników) stanowią około $0,1 \%$ ogółu przedsiębiorstw (raport Polska 2005). Warto zaznaczyć, że taka struktura przedsiębiorstw nie jest typowa tylko dla Polski. Występuje w niemal wszystkich krajach Unii Europejskiej. W 2004 r. odnotowano spadek o 1,2\% liczby zakładów osób fizycznych, przy czym od kilku lat systematycznie wzrasta liczba spółek handlowych.

Tab. 2. Liczba zarejestrowanych przedsiębiorstw w Polsce w latach 2001-2005 (według rejestru REGON)

\begin{tabular}{|l|c|c|c|c|c|c|c|}
\hline \multirow{2}{*}{ Rok } & \multirow{2}{*}{ Ogółem } & \multicolumn{7}{|c|}{ Przedsiębiorstwa według wielkości zatrudnienia } \\
\cline { 3 - 8 } & & $\mathbf{0 - 9}$ & $\mathbf{1 0 - 4 9}$ & $\mathbf{0 - 4 9}$ & $\mathbf{5 0 - 2 4 9}$ & $\mathbf{0 - 2 4 9}$ & $\mathbf{2 5 0}+$ \\
\hline 2001 & 3374956 & 3206452 & 131106 & 3337557 & 30809 & 3368366 & 6589 \\
\hline 2002 & 3468218 & 3302411 & 131480 & 3433891 & 28884 & 3462775 & 5443 \\
\hline 2003 & 3581593 & 3410233 & 137974 & 3548207 & 28329 & 3576536 & 5057 \\
\hline 2004 & 3576830 & 3402150 & 141499 & 3543649 & 28309 & 3571958 & 4872 \\
\hline 2005 & 3615621 & 3436841 & 145745 & 3582586 & 28343 & 3610929 & 4692 \\
\hline
\end{tabular}

Źródło: opracowanie autora na podstawie danych GUS 
Przedsiębiorczość w Polsce jest zróżnicowana regionalnie. Ogromna większość małych i średnich przedsiębiorstw działa w pięciu województwach (mazowieckim, śląskim, wielkopolskim, dolnośląskim, małopolskim). W tych województwach zarejestrowanych jest około 55\% wszystkich zarejestrowanych w Polsce małych i średnich przedsiębiorstw. Liczba przedsiębiorstw aktywnych w tych województwach wynosi około 54\% wszystkich aktywnych przedsiębiorstw w Polsce. Dla porównania: na obszarze pięciu województw o najmniejszej liczbie przedsiębiorstw (opolskiego, podlaskiego, lubuskiego, świętokrzyskiego, warmińsko-mazurskiego) zarejestrowanych jest około 14\% wszystkich małych i średnich przedsiębiorstw zarejestrowanych w Polsce.

W regionie południowym zarejestrowanych jest ponad 715 tys. małych i średnich przedsiębiorstw, co stanowi 19,8\% ogółu przedsiębiorstw tej wielkości zarejestrowanych w Polsce. Oznacza to, że region południowy znajduje się w czołówce regionów w Polsce. W ujęciu przestrzennym w woj. śląskim zarejestrowanych jest 11,8\%, a w woj. małopolskim 8\% ogółu przedsiębiorstw z sektora MSP zarejestrowanych w systemie REGON. Spośród przedsiębiorstw sektora MSP zlokalizowanych w regionie południowym, aż 94,65\% to mikroprzedsiębiorstwa, przy czym wskaźnik ten w woj. małopolskim wynosi 94,8\%, a w woj. śląskim 94,5\%. W woj. śląskim zarejestrowanych jest znacznie więcej dużych przedsiębiorstw (12,6\% w skali kraju) niż w woj. małopolskim (7,5\%). Bezwzględna liczba zarejestrowanych małych i średnich przedsiębiorstw jest wyższa w woj. śląskim niż w woj. małopolskim, przy czym rozkład przedsiębiorstw według wielkości zatrudnienia jest zbliżony (por. tab. 3 i 4). Jak wynika z prowadzonych przez Główny Urząd Statystyczny w 2004 r. badań strukturalnych ${ }^{1}$ aktywnych przedsiębiorstw, podmioty zatrudniające do 49 pracowników stanowiły 75\% wszystkich przedsiębiorstw aktywnych w woj. śląskim; jednocześnie był to najwyższy wskaźnik w kraju.

Tab. 3. Liczba zarejestrowanych przedsiębiorstw w woj. małopolskim w latach 2001-2005 (według rejestru REGON)

\begin{tabular}{|l|c|c|c|c|c|c|c|}
\hline \multirow{2}{*}{ Rok } & \multirow{2}{*}{ Ogółem } & \multicolumn{7}{|c|}{ Przedsiębiorstwa według wielkości zatrudnienia } \\
\cline { 3 - 8 } & & $\mathbf{0 - 9}$ & $\mathbf{1 0 - 4 9}$ & $\mathbf{0 - 4 9}$ & $\mathbf{5 0 - 2 4 9}$ & $\mathbf{0 - 2 4 9}$ & $\mathbf{2 5 0 +}$ \\
\hline 2001 & 270695 & 257596 & 10292 & 267932 & 2371 & 270303 & 392 \\
\hline 2002 & 278350 & 264649 & 10995 & 275644 & 2287 & 277931 & 419 \\
\hline 2003 & 285887 & 271479 & 11769 & 283248 & 2244 & 285492 & 395 \\
\hline 2004 & 288773 & 273892 & 12226 & 286118 & 2282 & 288400 & 373 \\
\hline 2005 & 289712 & 274329 & 12750 & 287079 & 2280 & 289359 & 353 \\
\hline
\end{tabular}

Tab. 4. Liczba zarejestrowanych przedsiębiorstw w woj. śląskim w latach 2001-2005 (według rejestru REGON)

\begin{tabular}{|l|c|c|c|c|c|c|c|}
\hline \multirow{2}{*}{ Rok } & \multirow{2}{*}{ Ogólem } & \multicolumn{7}{|c|}{ Przedsiębiorstwa według wielkości zatrudnienia } \\
\cline { 3 - 8 } & & $\mathbf{0 - 9}$ & $\mathbf{1 0 - 4 9}$ & $\mathbf{0 - 4 9}$ & $\mathbf{5 0 - 2 4 9}$ & $\mathbf{0 - 2 4 9}$ & $\mathbf{2 5 0 +}$ \\
\hline 2001 & 403004 & 381438 & 17130 & 398568 & 3665 & 402233 & 771 \\
\hline 2002 & 417945 & 395413 & 18201 & 413614 & 3597 & 417211 & 734 \\
\hline 2003 & 424031 & 401028 & 18779 & 419807 & 3541 & 423348 & 683 \\
\hline 2004 & 429173 & 405726 & 19293 & 425019 & 3526 & 428545 & 628 \\
\hline 2005 & 426266 & 402339 & 19825 & 422164 & 3510 & 425674 & 592 \\
\hline
\end{tabular}

Źródło: opracowanie autora na podstawie danych GUS

\footnotetext{
${ }^{10}$ Badania strukturalne prowadzone są na podstawie rozporządzenia Rady Ministrów RP w sprawie
} programu badań statystyki publicznej na dany rok. 
Nie stwierdzono rozbieżności w wartości przychodów ze sprzedaży pomiędzy przedsiębiorstwami zlokalizowanymi w województwach śląskim i małopolskim. Przedsiębiorstwa o przychodach poniżej 2 mln zł stanowiły w 2004 r. w woj. śląskim 33,9\%, a w woj. małopolskim 32,7\% wszystkich przedsiębiorstw. Dla przedsiębiorstw o wartości przychodów powyżej 25 mln zł wskaźniki te wyniosły $12,4 \%$ dla woj. śląskiego i $12,3 \%$ dla woj. małopolskiego.

W 2004 r. w przekroju terytorialnym najwięcej mikroprzedsiębiorstw prowadziło działalność na terenie województw mazowieckiego i śląskiego. Liczba mikroprzedsiębiorstw aktywnych w woj. śląskim wyniosła 209,3 tys. i stanowiła 12,7\% wszystkich najmniejszych przedsiębiorstw w Polsce. W woj. małopolskim zlokalizowanych było 142 tys. takich przedsiębiorstw, co stanowiło blisko 8,6\% mikroprzedsiębiorstw w Polsce. Łącznie w regionie funkcjonowała jedna piąta wszystkich aktywnych mikroprzedsiębiorstw w Polsce. Wysoki współczynnik aktywności mikroprzedsiębiorstw (relacja mikroprzedsiębiorstw aktywnych do zarejestrowanych), który w 2004 r. wynosił $52,1 \%$ (średnia dla kraju 48,5\%), jest ogromną zaletą regionu. W regionie południowym zaobserwowano zbliżone zagęszczenie badanych przedsiębiorstw mierzone wskaźnikiem drobnej przedsiębiorczości (wyrażonym liczbą mikroprzedsiębiorstw na 1000 mieszkańców), który wynosił 44,1\% (w woj. śląskim 44,5, w woj. małopolskim 43,6\%) wobec średniej dla Polski 43,3\%. Przeciętne zatrudnienie $\mathrm{w}$ jednym mikroprzedsiębiorstwie $\mathrm{w}$ regionie wynosiło 0,93 osoby na jeden zakład, a przy uwzględnieniu właścicieli mikrofirm 2,13. Przeciętne dochody mikroprzedsiębiorstwa z regionu południowego były w 2004 r. nieco wyższe niż w kraju i wynosiły 34,7 tys. zł, jest to jednak zasługa przedsiębiorstw zlokalizowanych na Śląsku, których rentowność jest wyższa (tab. 5).

\section{Podsumowanie}

Województwa wchodzące w skład regionu południowego od kilku lat stanowią trzon sektora MSP w Polsce pod względem liczby aktywnych przedsiębiorstw. Miejscem prowadzenia działalności gospodarczej przez dwie trzecie małych i średnich przedsiębiorstw regionu są gminy miejskie, przy czym relatywnie niewielka liczba przedsiębiorstw prowadzi działalność w gminach wiejskich. Małe i średnie przedsiębiorstwa zapewniają zatrudnienie ponad 1,2 mln mieszkańców, co stanowi dla woj. śląskiego 13,9\%, a dla małopolskiego 8,3\% wszystkich miejsc pracy oferowanych w regionie. W ocenie sytuacji należy uwzględnić samozatrudnionych prowadzących własne przedsiębiorstwa jednoosobowe. Region południowy odgrywa znaczącą rolę w obrotach handlowych małych i średnich przedsiębiorstw w kraju. Udział regionu w eksporcie małych i średnich przedsiębiorstw wynosi około $15 \%$, a w imporcie ponad $13 \%$, przy czym wskaźniki te dla woj. mazowieckiego nawet kilkakrotnie przewyższały prezentowane wskaźniki dla omawianego regionu, a woj. wielkopolskie zanotowało zbliżone wskaźniki do wskaźników województw małopolskiego i śląskiego łącznie. 
Tab. 5. Mikroprzedsiębiorstwa w regionie południowym w 2004 r.

\begin{tabular}{|c|c|c|c|c|}
\hline Kryterium & Polska & $\begin{array}{c}\text { Region } \\
\text { południowy }\end{array}$ & \begin{tabular}{c|c|} 
Woj. \\
małopolskie
\end{tabular} & Woj. śląskie \\
\hline \begin{tabular}{|l|} 
Liczba mikroprzedsiębiorstw \\
zarejestrowanych w rejestrze REGON
\end{tabular} & 3402150 & $\begin{array}{c}674380 \\
-\overline{19,8 \%}--\end{array}$ & $\begin{array}{l}273352 \\
--\overline{8}, \overline{0} \%\end{array}$ & $\begin{array}{c}401028 \\
-\overline{11,8 \%}-\overline{8}\end{array}$ \\
\hline Liczba mikroprzedsiębiorstw aktywnych & 1651200 & $\begin{array}{l}351335 \\
-\frac{21,3 \%}{0}--\end{array}$ & \begin{tabular}{|c|}
142033 \\
$8, \overline{6} \%$ \\
\end{tabular} & $\begin{array}{r}209302 \\
--\overline{12, \overline{7} \%} \\
\end{array}$ \\
\hline $\begin{array}{l}\text { Współczynnik aktywności mikro- } \\
\text { przedsiębiorstw (w \%) }\end{array}$ & 48,5 & 52,1 & 52,0 & 52,2 \\
\hline Współczynnik drobnej przedsiębiorczości & 43,3 & 44,1 & 43,6 & 44,5 \\
\hline $\begin{array}{l}\text { Liczba pracujaccych } \\
\text { w mikroprzedsiębiorstwach }\end{array}$ & 3389234 & $\begin{array}{l}749585 \\
-\overline{22,1 \%}-\overline{-}\end{array}$ & $\begin{array}{r}287855 \\
--\overline{8,5 \%}-\overline{0}\end{array}$ & $\begin{array}{r}461730 \\
--\overline{12,8 \%}-\overline{8}-\overline{0}\end{array}$ \\
\hline $\begin{array}{l}\text { Liczba pracujących w mikroprzedsiębior- } \\
\text { stwach na } 1000 \text { mieszkańców }\end{array}$ & 88,8 & 93,3 & 88,3 & 98,2 \\
\hline $\begin{array}{l}\begin{array}{l}\text { Liczba zatrudnionych w mikro- } \\
\text { przedsiębiorstwach }\end{array} \\
\end{array}$ & 1427541 & $\begin{array}{l}325421 \\
-\overline{22,8 \%}-- \\
\end{array}$ & \begin{tabular}{|c|}
121163 \\
$8, \overline{5} \%$ \\
\end{tabular} & $\begin{array}{r}204258 \\
--\overline{14,3 \%}-\overline{0} \\
\end{array}$ \\
\hline $\begin{array}{l}\text { Przeciętne zatrudnienie w jednym } \\
\text { mikroprzedsiębiorstwie }\end{array}$ & 0,86 & 0,93 & 0,85 & 0,98 \\
\hline $\begin{array}{l}\text { Przeciętna liczba pracujących w jednym } \\
\text { mikroprzedsiębiorstwie }\end{array}$ & 2,05 & 2,13 & 2,03 & 2,21 \\
\hline $\begin{array}{l}\text { Przeciętne wynagrodzenie miesięczne } \\
\text { brutto w drobnej przedsiębiorczości }\end{array}$ & 1391 & 1304 & 1292 & 1316 \\
\hline \begin{tabular}{|l|} 
Przychody na jedno mikro- \\
przedsiębiorstwo (w tys. zł)
\end{tabular} & 323,4 & 347,6 & 365,4 & 329,7 \\
\hline \begin{tabular}{|l|} 
Koszty na jedno mikro- \\
przedsiębiorstwo (w tys. zł)
\end{tabular} & 289,7 & 312,9 & 331,8 & 293,9 \\
\hline $\begin{array}{l}\text { Udział kosztów w przychodach } \\
\text { mikroprzedsiębiorstw (w \%) }\end{array}$ & 89,6 & 90,0 & 90,8 & 89,1 \\
\hline $\begin{array}{l}\text { Przeciętne dochody jednego mikro- } \\
\text { przedsiębiorstwa (w tys. zł) }\end{array}$ & 33,7 & 34,7 & 33,6 & 35,8 \\
\hline
\end{tabular}

Źródło: opracowanie autora na podstawie danych GUS 


\section{Literatura}

1. Aktualizacja raportu o stanie zagospodarowania przestrzennego kraju 2003, 2005, Instytut Geografii i Przestrzennego Zagospodarowania, PAN, Warszawa

2. Atrakcyjność inwestycyjna województw i podregionów Polski 2005, 2005, T. Kalinowski (red.), Instytut Badań nad Gospodarką Rynkową, Gdańsk

3. Dębski J., 2002a, Lokalne bieguny wzrostu w Polsce na przełomie XXi XXI wieku, t. 2, Wyższa Szkoła Finansów i Zarządzania w Białymstoku, Białystok

4. Dębski J., 2002b, Przedsiębiorczość prywatna w Polsce na przełomie XX i XXI wieku, t. 1, Wyższa Szkoła Finansów i Zarządzania w Białymstoku, Białystok

5. Opis sytuacji spoteczno-ekonomicznej województwa ślaskiego, 2005, Urząd Marszałkowski Województwa Śląskiego, Katowice

6. Ośrodki innowacji w Polsce, 2005, Agencja Rozwoju Przedsiębiorczości, Stowarzyszenie Organizatorów Ośrodków Innowacji i Przedsiębiorczości w Polsce, Poznań-Warszawa

7. Przedsiębiorczość w Polsce 2003, 2003, Ministerstwo Gospodarki i Pracy, Warszawa

8. Przedsiębiorczość w Polsce 2005, 2005, Ministerstwo Gospodarki i Pracy, Warszawa

9. Regionalne zróżnicowanie rozwoju gospodarczego [w:] Polska 2005. Raport o stanie gospodarki, 2005, Ministerstwo Gospodarki i Pracy, Warszawa

10. Rozporzqdzenie Rady Ministrów z dnia 27 kwietnia 2004 r. zmieniajace rozporzqdzenie $w$ sprawie wprowadzenia nomenklatury jednostek terytorialnych dla celów statystycznych NTS (Dz.U. z 2004 r., Nr 98, poz. 998)

11. Strategia rozwoju województwa ślaskiego na lata 2000-2020, 2005, Urząd Marszałkowski Województwa Śląskiego, Katowice

12. Surażska W., 1999, Potencjat rozwojowy województw 1999, Centrum Badań Regionalnych w Warszawie, Warszawa

13. Wielki Ranking Miast 2003, 2003, Centrum Badań Regionalnych w Warszawie, Warszawa

14. Województwo małopolskie 2004, 2005, Urząd Marszałkowski Województwa Małopolskiego, Kraków

\section{Potential of Small and Medium-sized Enterprises in Southern Poland}

The paper presents the synthetic diagnosis of the social and economical situation of the studied region, especially referring to the state and development tendencies of small and medium-sized enterprises in dynamic perspective, that is in years 2001-2005. The author presents conditions for small and medium-sized enterprises' functioning and development, which are laid in regional business environment, on the other hand he focuses on developmental tendencies of SMEs sector in the studied region. 